\title{
Labour in Pre and Post Liberalization
}

\section{Varun Otari}

\begin{abstract}
This paper is an attempt to capture an overview about labour movement in pre and post liberalization within India. A critical analysis of secondary available literature is carried out in order to understand various stands by the trade unions and industries over the period of time adopted in order to strengthen each other's side. Paper projects a view of strengthening collective bargaining between the unions and industries in order to ensure minimum wages and a better working condition. The focus is to energize labour movement within the country for better economy development of the society at large that will contribute towards nation's development
\end{abstract}

Keywords: Collective bargaining, Industry, Liberalization, Trade Union.

\section{INTRODUCTION}

Despite the high priority accorded to employment in development planning in India, elasticity of employment with respect to output declined since the early 1970s. Employment in the organized sector lagged output and at times, the population (Siddi, 1974). This is particularly true of employment in an organized manufacturing sector. The relative to output in 1980 s led many to describe the decade as one of jobless growth. The shocking experience cried for an explanation and employers had it ready. They blamed it on the labour flexibility introduced by labour unions and labour Dispute Act in 1976 and 1984. The change in the economic policy in 1991 shifted the discussion from the liberalization of the labour market to liberalization of all factors and product market in the country and gave it a global context. (Deshpande, 2004)

\section{INDIA'S LIBERALIZATION IN HISTORICAL PERSPECTIVE}

At the beginning of this century the Indian economy was an open one of the colonial type. India's British rulers were still convinced of the doctrine of free trade as long as it meant a race on a ladder on which they were ahead of everybody else. Except for a massive investment in the Indian railways which at this stage mostly benefitted British investors, the British had not done much for Indian internal development, but they had linked the country to the world market (Anjanuyulu V., 1969). India's exports consisted mostly of raw produce while it imported industrial commodities. The revenue base of British Indian state had shifted from land revenue and the salt tax as the mainstay of the budget to customs duties which were purely fiscal and were not supposed to have a protective effect.

Revised Manuscript Received on August 13, 2020.

* Correspondence Author

Varun Otari, M*., Development Sector Professional, Collective Bargaining, Tata Institute of Social Sciences, Mumbai, India.

(C) The Authors. Published by Blue Eyes Intelligence Engineering and Sciences Publication (BEIESP). This is an open access article under the CC BY-NC-ND license (http://creativecommons.org/licenses/by-nc-nd/4.0/) poor performance of organized manufacturing employment legislation particularly after the amendment of the Industrial

It was quite natural that nationalist interested in the internal development of India criticized this 'open economy'.

As early as 1877 Justice K.T. Telang had written a challenging paper on free trade where, he had carefully examined the objections to protectionism and had arrived at the conclusion that at least in cases like that of the cotton textile industry in a country like India which grew cotton in plenty and had an ample supply of labour, import substitution promoted by a protective tariff could be justified. The British rulers did not listen to him, but Indian nationalists repeated this message again and again. It was only when the British discovered the uses of market share in the interwar period that they abandoned the principles of free trade and opted for protectionism of a peculiar type. (Deshpande, 2004)

The First World War subjected India to the inevitable phenomenon of wartime inflation, but it also ushered in protectionism not as a policy but as a consequence of the relative isolation imposed upon India due to the interruption of maritime trade. Indian industrialists profited from the war and eagerly invested some of these profits in new machinery after the end of the war as they were optimistic about future economic development. In this they were disappointed and were burdened by idle capacities for a long time. This was particularly true of the cotton textile industry. The import of textile machinery had nearly doubled the number of looms, but this was not matched by a corresponding increase of production. The Indian textile industry had lost its export market to the Japanese after the war and demand in the home market did not expand so as to make up for this loss. The impact of the Great Depression and of Japanese competition then forced the British to adopt the protectionist policy mentioned above. Import substitution increased in India to some extent in the years of depression, but the loss of income of the peasants due to the steep fall of agrarian prices severely curtailed the purchasing power of the masses. It was only population growth which added to the demand for basic necessities. Population growth had stagnated in India in the first two decades of the twentieth century. This was due to the consequences of famines and diseases. Miraculously it was observed as increase in the per capita income of the country. After 1920 population growth got up with economic growth and reduced per capita income. Thus the late 1920 and 1930s were a bad time for India. The only people who had a good time were the urban salaried men whose fixed income endowed them with increasing purchasing power as the prices of commodities declined. This was also true of urban labourers whose wages could not be easily adjusted for failing prices. Thus the 1930s witnessed a rise in real wages which was conspicuous by its absence before and after that period. 
The Second World War affected the Indian economy in much the same way as the first one. But the dimensions of the impact of the war were now much greater, the war profits of Indian industrialists were higher, the real wages declined as agricultural prices rose once more. Inflation increased as the British absorbed a great deal of India's industrial production, paying for it by adding to India's reserves in the Bank of England and meanwhile printing money for circulation in not only got rid of it 'national debt' in this way but emerged after the war as a creditor of its colonial masters. This acted in the favor of India, as it was convenient to grant independence to a debtor than the country that owes money to the British. Further, India had to absorb about 1.5 million demobilized soldiers as about 2 million soldiers had served the British on various fronts. The British - Indian government had entered the war still wedded to the old principles of economic liberalism as far as the internal economy was concerned. The principles of economic liberalism had been abandoned only in the field of foreign trade. British India was turned into an interventionist state with a vengeance in the course of the war. In this context, the next half of the twentieth century acted as a major source of the building of institutions.

Jawaharlal Nehru, the architect of India's rapid industrialization, used the inherited instruments of the interventionist state to realize his dream of India as a modern productive nation. Import substitution was his main aim. The Telang's argument was still valid. Hardly anybody would remember him in the 1950s, but by now protectionism and import substitution were the order of the day. Nehru trusted that industrial growth would finally lead to agricultural advance, but he obviously did not wish to rely on the millions of Indian peasants as harbingers of India's economic future. Moreover, ever since the depression land revenue had not been enhanced, the income from the revenue did not even cover the cost of its collection. Thus the government would not have much of an active interest in agriculture. The peasant was important as voters only. Nehru tried to keep agricultural prices down so as to keep urban wages within limits in order to safeguard industrial growth. He did not live to see the collapse of his policy in the mid-sixties under the impact of two years of severe drought. Planning was practically suspended at that time and a long industrial recession slowed down India's economic growth. Agriculture was benefitted by the Green Revolution which made it felt in the 1970s this did not lead to a revival of industrial growth. Some Indian critics of the government's economic policy regard the 1970s as a lost decade which impaired India's chances of catching up with other newly industrializing countries. The 1980s began with an episode which many Indian policymakers regarded as a humiliating defeat of their endeavors: India has to turn to the World Bank and IMF for help. At this stage it may suffice to state that India managed to do without this help very soon and then embarked on a course of cautious liberalization. Industrial growth accelerated once more and the 1980s looked much better that the 1970s in indiscipline and a lack of internal liberalization. The central government had windfall gains from the sudden increase of income from customs duties. It must be stressed at this point that this development had adverse consequences in terms of structural maladjustment which made structural India. The political benefit of this procedure was that India

adjustment more painful in the 1990s. Finally the crisis of 1991 came as a boon in disguise. Since the parallel change in the political scene enabled India to present itself under new management, the immediate crisis was overcome very quickly, but this also reduced the urgency of further reforms. Structural adjustment was understood only in the usual macro-economic terms whereas institutional factor were mostly ignored, eg., power shortages due to inadequacies of the energy sector, the bad management of the railways which diverted a great deal of transport to the roads which were already overburdened, the chaos in the Indian ports which makes their operation very slow and costly etc. This list could be extended and in the discussions in the seminar many more instances of institutional bottlenecks were mentioned. The subsequent sections of this introduction will be addressed to such institutional problems. There will be no exhaustive treatment of such bottlenecks. The main aim is to draw attention to them so as to correct the macro-economic approach to structural adjustment. Fortunately recent trends of economic thought have favored a renewed attention to institutional factors. Historians have always been interested in institutions, but when economists parted company with historians at the beginning of this century and stressed the affinity of their discipline to the natural sciences, they also lost sight of the relevance of institutions. In dealing with India an institutional approach to economic development is particularly important, because institutional structure and the forces of the market have often been opposed to each other rather than supporting each other. (Dietmar, 1996)

\section{LABOUR FLEXIBILITY: THE GLOBAL CONTEXT}

Neoclassical economist has been rightly criticized for building more ornate structures on shaky foundations. This is nowhere as true as in labour economics. Everyone agrees that labour is not a commodity but most textbooks in labour economics contain little else besides application to the sale and purchase of services of labour the apparatus being borrowed lock, stock and barrel from the product market. With appropriately sloped demand and supply curves, the student is assured of an equilibrium, which restores itself if displaced by changes in tastes, technology or whatever. He is assured that it does so the quicker the prices and quantities of labour respond to the change. He is told that flexibility of response is essential if the society is to banish unemployment.

The mental and physical capacity to work is embodied in the worker, a human being, who has to deliver it to the employer. The lease of this capacity to lessee creates no difficulties in the abstract model. It does in the real world. First human beings are not motivated by gains alone, least of all by monetary gains alone. More often, the behaviour of the employer and the employee may be based on strategic considerations. It has been always observed the reluctance of the employer in paying its employee in return of its labour work.

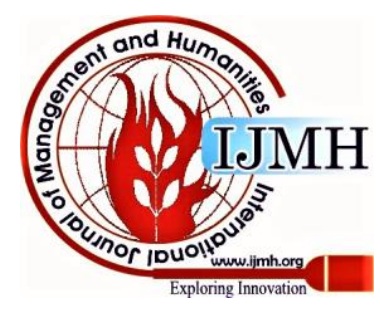


On a similar note, employee put forward its demand in order with an opinion of not getting it fulfilled even though they were being reasonable. Secondly theory of contracts is of little help because the quantity and quality of labour bought and sold cannot be precisely defined. Neither the buyer of labour nor its seller knows what each is in for when they enter into a contract. Because information is incomplete and often asymmetric most labour contracts are neither complete nor easily enforced. Therefore, most explicit contracts are accompanied by an implicit complement often based on trust. To the liberalization, fairness and justice lies in delivering the contract. But, as Solow (1990) argues, the labour market is more a social than an economic institution where social and cultural norms play a crucial role. If the $19^{\text {th }}$ century, particularly its third quarter 1848-75, belonged to labour, Then the latter was more rigid and stable phase of production and distribution in the industrialized country. Those were the halcyon days of the two models, welfare state capitalism and state socialism. Though both aimed at de-commodification of labour or making labour market less like commodity markets, the proponent of each would rather expect or want the less developed countries to follow the model they were advocating. Both offered full employment and individual and collective security. State socialism offered security from the cradle to the grave but very little freedom. The many variants of welfare state capitalism that prevailed in Western Europe were based on the Keynesian approach. Macroeconomic policy was used to achieve and maintain full employment and micro economic policy was used to control inflation and improve efficiency. These initiatives offer a major coverage to an employee that will cover the basic fundamental requirements of his/her lives.

Globalization and Liberalization led to a reduction in restrictions on movement of goods, services and capital and application of information technology reduced the transport and production cost all round. New technology made capital mobile and increased its bargaining strength relative to labour and state. Capital could withdraw from a state with higher taxes and higher labour regulation to another with less of either or both. The rise of Japan and the newly industrializing countries from rags to riches posed challenges to the developed countries. The newly industrializing country not only did not ratify most of the International Labour Organization convention but some of them repressed labour and unions. However they invested in education and training, protected domestic industry behind high tariff in the initial stages but lowered them over time forcing it to be internationally competitive. Many multinational corporations shifted some of their production lines to these countries to profit by the availability of cheap labour and absences of stringent anti-pollution laws. Initially, when the volume newly industrializing countries export to the developed countries and the outflow of the capital from the developed countries was negligible, the threat to jobs in developed countries went unnoticed. But as newly industrializing countries exports and developed countries capital outflow increased, the fear of de-industrialization roused the nationalist rabble. Globalization is everywhere followed by privatization. In the low developed countries that have accepted conditional loans for structural adjustment, privatization is one of the conditions. The major thrust in all countries, developed and developing, is to reduce the size of the government so as to reduce bureaucratic inefficiency and transaction costs and to attract foreign investment. Though many reasons such as market failure, missing markets, which justify the large size of the government in the low developed countries, were not relevant to developed countries, the government in the developed countries acted as employers of the last resort and used public employment as an instrument for achieving full employment. The refusal of the government to play this role sent a signal to denationalize firms to downsize. Mass unemployment was considered proof positive of absence of flexibility. Neo classical theory predicated full employment assuming flexible product and factor prices and blames less than full employment on market rigidities. Flexibility is easier to practice when large unemployment exists. Unemployment weakens the bargaining position of the workers and enables employers to employ workers on terms and conditions of work that they dictate. Political economy perspective views flexibilization as a political struggle in order to understand the change that will be emerged out of flexibilization in the industrial world. Political will and policies are the key for any urban setting development that lead to the benefit of an employee's life and as well as for an employer's business.

\section{GLOBALIZATION \& FLEXIBILITY}

\section{a. Production Flexibility}

It is claimed that Fordism or mass production is dead and we are in the days of small establishments and flexible specialization. Yet, multinationals have grown enormously in size and control increasing their share of global income. As far as labour is concerned, decentralization has increased. Large firms have explored various mechanism and way out to outsource their production at multiple locations across the globe. Globalization and technological change have increased uncertainty structures to reduce the risk and uncertainty by vertical disintegration including decentralization production.

\section{b. Wage System Flexibility}

Since the emergence of a supply side economy, wage flexibility has become a panacea. Absence of flexibility causes unemployment, inflation and stagnation in growth and pain in structural adjustment; its presence ensured low unemployment, stability and growth. Wage flexibility is increasing in the developed and developing economies. Wage differentials have widened and the share of wages in national income fallen. Unit labour costs through low were alleged to be high enough to affect international division of labour or for firms to shift location. This has contributed to statutory deregulation in the developed countries.

\section{c. Employment or Numerical Flexibility}

Numerical flexibility refers to ability of firms to become more competitive by reducing job opportunities with low amount of costing. Employers allege that statutory regulation has made quick dismissal difficult and prohibitively costly.

Published By:

Blue Eyes Intelligence Engineering \& Sciences Publication

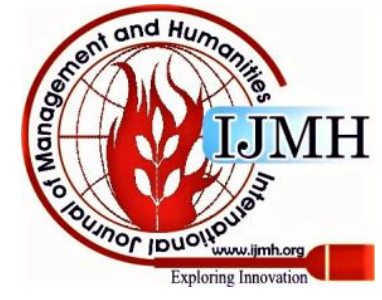


This has led to firms' not hiring labour even when demand increased. They rely on flexible worker categories or contingent labour to meet the increased demand or use capital intensive technology. The firm's internal labour market has been characterized in dualistic terms such as primary and secondary, core and periphery and formal and informal. Some of the emerging labour categories are mentioned below:

(i) Casual, Temporary and Permanent temporary worker: Casual workers are hired for fixed hours mostly at piece rates and lack employment security. Temporaries have a fixed term contract. Permanent temporaries are a form of workers those stay with the companies but are never on the role of companies and lack all the benefits of a permanent employee. (ii) Consultant: This is a growing tribe with wide skills. No regulations apply to them. (iii) Subcontractors: Firms out-source many activities they use to do in house. Many family firms or individuals, who do not work directly for any employer but are in a dependent relation to other enterprises, work on a piece rate or job work basis. (iv) Agency workers: Large and small firms approach private agencies to supply dependent workers and do not possess independence that the self-employed or own account workers have. (vi) Teleworkers: Teleworkers work from home but have greater control over their skills, means of production and labour. (vii) Part-time workers: The definition of part time work depends on how standard work week or day is defined. (viii) Concealed workers: They are employed informally in illegal

\section{d. Work Process Flexibility}

When technology or market changes, firms would want to change how the work is organized. The speed and ease with which a firm can adapt to technological innovations and market fluctuations by altering established practices of working time, job mobility and flexibility and Tayloristic control is called functional flexibility. Shift working, overtime and variable working hours are various ways of flexi time working through which functional flexibility is achieved. Functional flexibility is linked to external flexibility and is facilitated by forms of non-regular labour. (Deshpande, 2004)

\section{METHODOLOGY}

Type of Research: Qualitative research

\section{Research Design and Procedure}

This research is a complete exploratory in nature and analyzing facts states in the available literature. A detailed secondary data analysis has taken up in order to understand the various parameters associated with the labour movement in the pre and post era of liberalization. An extensive secondary research has given an insight about various key decisions and policy changes in the country affecting labour movement. This study leans towards qualitative approach and uses qualitative framework of analysis. Qualitative research is concerned with individuals own account of understanding towards the topic. Hence a rigorous analysis of Acts, historical evidences and academic papers was conducted in order to understand the various point and juncture of the labour movement the workers. (v) Home workers: They work from home as activities or black economy

Source of Data Collection: Secondary data has been utilized

for data collection

Data Analysis: Content analysis to understand the overall impact of various incidences on the labour movement within the country. In depth analysis is been made to understand and make inferences from the data collected

\section{ECONOMIC REFORM IN INDIA}

\section{a. Introduction}

Foreign Direct Investments (FDI) is a boon for an Indian economy. On the relaxation of the norms by the countries over FDIs, it has always opened up to multinational companies for expansion of its businesses. On understanding the benefits of FDI, India opened up its economy for FDIs post 1991 (Rothermund, 1996). This liberalization of economy brought in a various opportunities to the country. Within no time, India gained its fame about its geographical importance, about its cheap labour availability and a hub of knowledge that attracted multinational enterprises to set up its operation in the country. This acceptance of the industrial change introduced India for a new technological change in the working environment. On pre-conditions of local collaborations within the country, these investments were introduced to the economy. (Bhatia \& Singh, 2003)

\section{b. Pre Liberalization Labour in India}

Before liberalization it was assured a descent working conditions, enough minimum wages and job securities to all the working class of the country with an aim to strengthen trade union operations in the country. During this course of action, Government had played an important role in drafting and implementation of labour laws in the country for smooth collaborations between trade unions and industries. These laws specifically dealt with regulation of working hours, working conditions, minimum wages and more importantly collective bargaining (Zagha, 1999: 169). At an extent these laws came to the rescue of labourers in the country by improvising the working conditions at the industry. A major contribution from these laws were that, now trade unions become more dependent on Government for resolution of any sort of issues in the country. This emerged as a new strategy known as third party collective bargaining in the country. In fact in the upcoming days it occurred that this third party collective bargaining has majorly contributed in weakening of labour movement in the country (Ramaswamy and Ramaswamy, 1981:201). Ultimately the identity of the trade unions remained narrowed in the form of lack of ideologies, poor leadership, no vision, rivalry, industrial conflict etc. Simultaneously, due to existence of unorganized labour work force significantly contributed towards the failure of trade unionism within the county. Even though the trade union movement was active in the country, still it did not managed to address key social issues of the society. That included, unemployment, lack of working conditions for unorganized sector, regulation of contract workers etc.

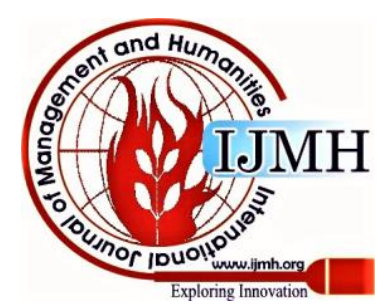



industrial relations has always remained superficial. That concludes that any recognition of the trade union would not be mandated to the Government for its recognitions. Further it also conveys that, even though there is an elected union within the industry still is won't become a sole representative of all the workmen. This gives an opportunity to employer to motivate its rival union to counter the elected union and support management decisions. This has emerged from the labour laws of the country that open up a scope for workmen to make multiple unions under the one roof of an industry. Due to these conflicts and strategies, it has significantly contributed to weaken the trade union movement in the country. In return it occurred that, even though with the prominent history of trade unions in the country it has never grown above the mark of 6 per cent. On considering all facts and figures about trade unions in the country the contributions made by it towards labour benefit has been very minimal.

\section{c. Post Liberalization Labour in India}

Various packages those were wrapped in as a gift of economic liberalization post 1991 was of very minimal usage to a trade union. The main focus of economic transformation has been to motivate foreign direct investments in the country by easing on the rules and regulations for the investments. It had increased market value and demand at a magnificent level that principles of descent working conditions, equal pay and job securities remained at the back track. Liberalization gave an added advantage to the employers to move towards casualization of the work and motivated contractual working force for getting its work done. This had put labour at risk to be as a secured individual in a highly technological driven market. A complete different form of working environment was visible in this highly productive technological market (Gosh, 2000:32). In order to remain competitive in high paced industrial market, schemes like Voluntary Retirement and implementation of exit policy were widely adopted for the non-productive units of the industries. Further these adoptions of new strategies of retrenchment, significantly contributed towards closure of units and outsourcing of productions within the country. That led to propose for flexible labour policies for special economic zones of various states in the country. Due to such fast paced expansion of the free market. The existence of trade unions remained diluted. With this due to crisis of existence for the trade unions, it led to various incidence those have made headlines. Few of them include setting of Honda Plant in Haryana, Industrial relations crisis issues in Suzuki Maruti Plant in Manesar etc. The mere focus of these identity crises was to mark the presence of trade unions in the countries. Further this idea of vandalism was not supported by Government and by the larger society. The support of larger society was much need for surviving of trade unions in the country as these workers are also representatives of the same society (Agarwal, 1982).

With this in order sustain any investors in the country; Government began its amendments in the trade union's Act. It became important for trade unions to prove its majority support in the industry. On failure of it, the recognition as a representative of workforce by the trade union remained on hold. In other terms, any trade union with
The overall involvement of the government in the

no support from its workmen will not gain any affiliations from political parties and as well as from the management for bargaining purpose. The goal of one industry one union has become and obsolete idea. Thus, it secured a stronger bargaining power to management in shaping their own terms and conditions in order to earn more profits. The growth of economy has directly hit on the right of association of an individual for effective bargaining of his/her own rights. The outsourcing of products has led down to more number of sick units and closure of such leading to higher number of unemployment in the country. Traditional industries like weaving, handicrafts etc have now been on the verge of extinctions. It should be noted here that due to closure of units, the rising unemployment has significantly embarked as a contributor for failure of labour movement. It is visualized that those trade unions that fails to secure rights of its members, the membership declines and that benefits the management for putting forward its demand for increase in productivity. The overall working conditions and structure of organizations has changed. It has witness a lot of leniency in working and casualization of work that don't fit into the idea of trade unions mode of operations.

\section{RESULT ANALYSIS}

Importantly there is a diverse change in overall operation of a trade union or a labour movement within the course of the time. From the beginning till date the struggle what it has occurred in the history and post liberalization has always been around fixing of minimum wages. Various economic policy has been brought up by ruling government in order to strengthen the economy but it occurs that a very minimal consideration to the labour has been made in it. It revealed that the working structure has been complete altered by adopting casual form of working style. The dilution of unions within the country had motivated a lot more generation of unorganized sector. Role of government is important in the nation as well as in the development of an individual. An individual belongs from the grassroots and they have always participated in these movements for assuring bare minimum fundamentals for his/her own family. Post liberalization, country has very conveniently visualized a shift in the labour movement that has merely marked its presence within the country. As per the state research it occurs that a lot more changes will be visualized as the technological progresses will be made in upcoming day.

\section{CONCLUSION}

The question that has arisen is that those workers who are unskilled, unemployed and traditional old fashioned what happen to them? Though they got VRS from their company what has been achieved by them after getting it? Whether these people were able to sustain themselves and their families as well? These and many such questions arise but all questions are unanswered and doubtful.

Published By:

Blue Eyes Intelligence Engineering \& Sciences Publication

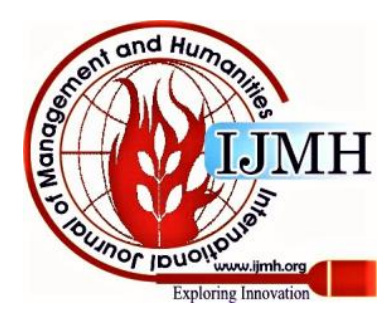




\section{Labour in Pre and Post Liberalization}

The role of government change from being protector to these trade unions changed to as a mediator gave no significant securities of job to the workers. The casualization of work let to more unemployment and more motivation of unorganized sector and outsourcing of the products. There is a need to revive the labour trade union movement in order to curb the menace of unemployment within the country and to significantly contribute towards nation's development. Further it is crucial to introduce leaders from labour movement into the political arena to put forward the plight of unemployed and unorganized labour in the country. One industry one trade union need to be adopted as in order to strengthen the labour movement and to avoid inter union rivalries. More emphasis of trade unions needs to be towards societal development than being individual development.

\section{REFERENCES}

1. Ashwathapa K., 2008, Human Resource Management Text \& Cases, Tata McGraw Hill Publishing Company Limited, New Delhi.

2. Anjanuyulu V. 1969, Gandhian Concept of Industrial Relations and Its Influence on Indian Labour Policy, Indian Journal of Industrial Relations, Vol. 5, No. 2, pp 123-146

3. Ashraf Siddi. Oct 1974, Political Affiliations of Industrial Workers: An Area Study, Indian Journal of Industrial Relations, Vol. 10, No. 2, pp. 197-206

4. Jenson H. Vernon, Jan 1956, Notes on the Beginning of Collective Bargaining, Industrial and Labour Relations Review, Vol. 9, No. 2, pp. 225-234

5. Sheth N.R., 1977, Towards Industrial Democracy, Economics and Political Weekly, Vol. 22 No 22, pp 2

6. Srivastava D.K. April 2006, Trade Union Response Declining Membership Base: Best Practices from Mumbai Based Trade Unions, Indian Journal of Industrial Relations, Vol. 41, No. 4, pp 355-374

7. Sur Mary, 1965, Collective Bargaining, Asia Publishing House, Bombay, 1965

8. Common John R., 1950, The Economics of Collective Action, The Macmillan Company, New York, 1950

9. Thakur C.P. July 1976, Trade Unions and Social Science Research in India, Indian Journal of Industrial Relations, Vol. 12, No. 1, pp 1-26

10. Vaid K.N. 1965, Why Workers Join Unions, Indian Journals of Industrial Relations, Vol. 1, No. 2, pp. 208-230

11. Syverson Chad, 2011, What Determines Productivity? Journal of Economic Literature, American Economic Association, America

12. Dietmar Rothermund, 1996, LIBERALISING INDIA, Progress and Problem, Manohar Publishers \& Distributors, New Delhi.

13. Bhatia, S.K \& Singh Nirmal, 2000, Industrial Relations and Collective Bargaining, Deep \& Deep Publications, New Delhi

14. Agarwal, D.V. 1982, Industrial Relations and Collective Bargaining, Deep \& Deep Publications, New Delhi

\section{AUTHORS PROFILE}

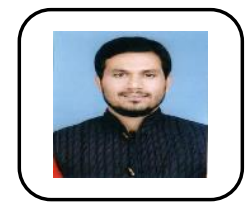

Varun Otari, M., Phil Graduate in the subject of Collective Bargaining from Tata Institute of Social Sciences, Mumbai. Currently working as a Development Sector Professional in the field of Children with an experience of more than 6 years 